\title{
The Measurement of Rare Plants Learning Media using Backward Chaining Integrated with Context- Input-Process-Product Evaluation Model based on Mobile Technology
}

\author{
Nyoman Wijana ${ }^{1}$ \\ Department of Biology Education \\ Universitas Pendidikan Ganesha \\ Bali, Indonesia
}

\author{
Ni Nyoman Parmithi ${ }^{2}$ \\ Department of Biology Education \\ IKIP PGRI Bali \\ Bali, Indonesia
}

\author{
I Gede Astra Wesnawa ${ }^{3}$ \\ Department of Geography Education \\ Universitas Pendidikan Ganesha \\ Bali, Indonesia \\ I Made Ardana ${ }^{4}$ \\ Department of Mathematics \\ Education \\ Universitas Pendidikan Ganesha \\ Bali, Indonesia
}

\author{
I Wayan Eka Mahendra ${ }^{5}$ \\ Department of Mathematics \\ Education \\ IKIP PGRI Bali \\ Bali, Indonesia
}
Dewa Gede Hendra Divayana ${ }^{* 6}$
Department of Information
Technology Education
Universitas Pendidikan Ganesha
Bali, Indonesia

\begin{abstract}
This research was aimed to know the effectiveness level of learning media utilization to the introduction of rare plants in Alas Kedaton tourism forest in Tabanan-Bali based on backward chaining for students and the general public. The type of this research includes explorative and evaluative research types. The population in this study was the plants species that exist in the Alas Kedaton tourism forest. The human population was the entire society in the area of Alas Kedaton tourism forest. The sampling method of plants species used the quadratic method, while for the human samples used purposive sampling method. The data has been collected then analyzed descriptively. The results of this study indicate that through the utilization of learning media obtained related information about the number of rare plants species in Alas Kedaton tourism forest as many as 48 species of plants with 26 families, and also the factors causing the scarcity of those plants species. Through the use of CIPP (Context-Input-Process-Product) evaluation model assisted by mobile technology, the overall average effectiveness of learning media utilization to the introduction of rare plant in Alas Kedaton tourism forest in Tabanan-Bali based on backward chaining amount of $88.20 \%$, so that was included into the good categorization.
\end{abstract}

Keywords-Rare plants species; backward chaining; evaluation; CIPP; mobile technology

\section{INTRODUCTION}

Forests are one source of foreign exchange that has been massively exploited for timber. This exploitation leads to widespread forest loss. Until now, the destruction of the forest environment still occurs, both by the practice of illegal logging and illegal mining. Based on the data from the Planology Department of Forestry in 2010 [1], it is known that forest destruction is getting worse due to uncontrolled logging, forest fires, community utilization of timber, and the conversion of land functions in forests. Based on data from the Bali Forestry Office in 2010 [2], the area of the mainland forest in Bali is $127,721.01$ hectares or only 22.59 percent of the total area of Bali's land area of 563,286 hectares. In addition to natural disasters of drought, floods and landslides, forest destruction also causes extinction of plant species contained therein. Including local plant species that are very important for science because some of them are the types of plants that have been threatened in nature and unique plant species and endemic or have a uniqueness or very rarely found elsewhere.

Some studies may be mentioned, such as the research that has been done by Wijana in 2004 [3], 2005 [4], 2006 [5], 2008 [6]; 2009 [7], 2010 [8], 2012 [9], 2013 [10], 2014 [11], 2015 [12], and 2016 [13]-[15]. All his research is done in the area of Bali. Researches related to the analysis of terrestrial vegetation outside of Bali have been done by Arrijani, et.al. in 2006 [16], Sri Hartini in 2007[17], Purwaningsih in 2006 [18], Purwaningsih and Razali Yusuf in 2008 [19], Junaedi, Indrawan, and Mutaqien in 2010 [20], and Onrizal, et.al. in 2006 [21].

In general it can be said that the studies mentioned above, examine the composition of species, species diversity, and management of protected forests and national parks. These studies were conducted in areas such as Arrijani in Cianjur, Junaedi in West Java, Sri Hartini in East Kalimantan, Onrizal in West Kalimantan, and Purwaningsih in Southeast Sulawesi. The context of this study is more oriented to study vegetation parameters or vegetation analysis and efforts to introduce rare plants in forest areas through learning media and evaluation of the effectiveness of the utilization of learning media. 
One of the forest areas used as tourist attractions in Bali is Alas Kedaton forest, Kukuh village, Marga district, Tabanan regency, Bali, Indonesia. According Sujaya in 2007 [22] explains that the width of Alas Kedaton tourism object is approximately 12 hectares, while the forest area of hedge approximately 6.5 hectares. In this forest area found the trees are large and dense, and there are several types of plants in the forest vegetation, is included in the category of rare plants.

As an effort to conserve protected forest in Alas Kedaton tourist area, it is necessary to introduce to society in general and the students in particular about information of rare plant species that exist in the area through mobile technologyassisted learning media. With the help of mobile technologyassisted learning media, the community and students can search and complete information about the rare plants in Alas Kedaton forest, Tabanan, Bali through the media whenever and wherever they are. To obtain an overview of the effectiveness of learning media utilization for introduction of rare plants in Alas Kedaton tourism forest, Tabanan, Bali, it is necessary to conduct an evaluation.

Generally evaluation is an activity to collect, process, and analyze a data into accurate information through a meticulous, complete and in-depth measurement process that can be useful as a recommendation for stakeholders/policy in taking a right decision. That definition of evaluation is reinforced by Divayana and Sanjaya [23], Jampel, et.al. [24], Arnyana, et.al. [25], Divayana, et.al. [26]-[29], Ariawan, Sanjaya, and Divayana [30], Divayana, Ardana, and Ariawan [31], Divayana [32]-[36], Sanjaya, and Divayana [37], Divayana, and Sugiharni [38], Divayana, Adiarta, and Abadi [39], Suandi, Putrayasa, and Divayana [40], Divayana, D.G.H., Adiarta, A., and Abadi [41], Sudiana, et.al. [42], Mahayukti, et.al. [43], with the core of the definition of evaluation is an activity to obtain recommendations so that it can be used as a basis for decision-making to continue/stop the program being evaluated.

There are several evaluation models that can be used in an evaluation such as: Goal Free Evaluation Model, Goal Oriented Evaluation Model, Responsive Evaluation Model, Formative-Summative Evaluation Model, Countenance Evaluation Model, Center for the Study of EvaluationUniversity of California in Los Angeles, CIPP (Context, Input, Process, Product), and Discrepancy Model.

From some of these models, the most suitable and appropriate model used in this study is the CIPP evaluation model, because this model can provide related information: 1) the evaluation context that provides value and description of the things that cause learning media to introduce of rare plants in Alas Kedaton tourism forest can be realized, 2) evaluation inputs that determine the available resources, alternative strategies and what plans should be done to encourage the holding of learning media, 3) evaluation process that provides value and description of the activities that have been implemented to achieve the objectives of the implementation of the learning media, and 4) evaluation products that provide value and description of the results achieved after utilizing the learning media.
From the description above, the problems studied in this research are: 1) How the use of learning media to introduce of rare plants, especially in Alas Kedaton tourism forest to know the number of species of rare plants in that forest and the factors causing the scarcity of the plant species; 2) What is the effectiveness level of utilization of learning media to introduce rare plants in Alas Kedaton tourism forest for students and the general public?

Based on the problems and the use of a new innovation in the form of learning media as a solution to problem solves the existing problems, so the researchers are interested in conducting research studies about the effectiveness measurement of the learning media for introduction of rare plants in Alas Kedaton tourism forest in Tabanan-Bali using backward chaining integrated with Context-Input-ProcessProduct evaluation model based on mobile technology

\section{RESEARCH METHODOLOGY}

The type of this research includes explorative research and evaluative research. It said explorative research because it explores of rare plant species in the Alas Kedaton forest tourism in Tabanan, Bali, Indonesia. It is said evaluative research for evaluating of learning media to introduce of rare plants in Alas Kedaton forest tourism. The explorative research location in Alas Kedaton tourism forest is with an area of 6.5 hectares. While the location of evaluative research conducted in the area of Alas Kedaton tourism object and high school around in Alas Kedaton Tabanan.

Population in this explorative research was plant species that exist in Alas Kedaton tourism forest. The population of evaluative research was the entire community in the area of Alas Kedaton tourism forest. The sampling method of plant species for explorative research was using the quadratic method [11], [44], while the community sampling method for evaluative research is by using purposive Sampling. The samples of plant species are all plant species covered by squares of $20 \times 20 \mathrm{~m}$ size as many as 100 squares. For the sample of the community was taken as many as 25 people.

In the sampling technique of plant species using systematic squares, the squares are placed continuously at $10 \times 20 \mathrm{~m}$ intervals along the line of the compass line, as many as 100 squares. Each square is recorded for its constituent plant species. Plant species that have been collected then determined the species of plants that fall into the rare category. The determination of this rare plant species is done by studying existing documents, conducting interviews, and seeking information from various sources. Furthermore, with in-depth interviews with sources of informants from the community around the forest area, and including the District and Provincial Forest Service, to obtain information related to rare plants that fall into the national rare category, rare at the level of Bali province, scarce at Tabanan regency level, and Rare at Marga and Kukuh Village levels. Further data were analyzed descriptively. In purposive sampling technique of society in evaluating learning media conducted with the intention of involving parties who have interests/goals and understand the object/program studied in this case related to learning media to introduce of rare plants in Alas Kedaton forest tourism. The evaluation results using the CIPP model 
on the use of learning media to introduce the rare plants in the Alas Kedaton tourism forest are indicated by the average percentage of effectiveness calculated using the following percentage descriptive formula [45].

$$
\Sigma(\text { Answer * Weight of Each Choice) }
$$

Percentage $=$ $* 100 \%$

$$
\mathrm{n} * \text { The Highest Weight }
$$

Notes:

$$
\begin{array}{ll}
\Sigma= & \text { Amount } \\
\mathrm{n}= & \text { Total number of questionnaire items }
\end{array}
$$

Furthermore, to calculate the percentage of all subjects used by using the following formula:

$$
\mathrm{F}
$$

Percentage $=$

\section{$\mathrm{N}$}

Notes:

$\mathrm{F}=$ Total percentage of the entire subject

$\mathrm{N}=$ Number of subjects

To be able to give meaning and decision on the percentage level of effectiveness/achievement, then used scale conversion effectiveness level as follows [45] (Table I):

TABLE I. CONVERSION LEVEL EFFECTIVENESS By SCALE OF Five

\begin{tabular}{|l|l|}
\hline Level of Effectiveness & Category \\
\hline $90-100 \%$ & Very Good \\
\hline $80-89 \%$ & Good \\
\hline $65-79 \%$ & Enough \\
\hline $55-64 \%$ & Less \\
\hline $0-54 \%$ & Very Less \\
\hline
\end{tabular}

\section{RESULTS AND DISCUSSION}

\section{A. Result}

Recapitulation of explorative research results on plant species present in Alas Kedaton tourism forest, presented in detail in the Table II.

There are a total of 48 plant species found in the Alas Kedaton tourism forest, which belongs to 26 families, with details of the following families: Meliaceae (8 species), Moraceae (7 species), Lauraceae (3 species), Annonaceae (3 species) (2 species), Apocynaceae (2 species), Sterculiaceae (1 species), Lythraceae (1 species), Euphorbiaceae (1 species), Clusiaceae (2 species), Myocycaceae (2 species) (1 species), Phyllanthaceae (1 species), Rubiaceae (1 species), Caesalpinioceae (1spesies), Sabiaceae (1 species), Elaeocarpaceae (1 species), Verbenaceae (1 species), Malpighiaceae (1 species), Cornaceae (1 species), Rubiaceae

\begin{tabular}{|c|c|c|c|}
\hline \multirow{2}{*}{ No } & \multirow{2}{*}{ Family } & \multicolumn{2}{|c|}{ Name of Plant Species } \\
\hline & & $\begin{array}{l}\text { Local Name*/ } \\
\text { Indonesia }\end{array}$ & Scientific Name \\
\hline \multirow{2}{*}{1.} & \multirow{2}{*}{ Anacardiaceae } & Dau & $\begin{array}{l}\text { Dracontomelum } \\
\text { mangiferum }\end{array}$ \\
\hline & & Mete Mini & Semecarpus cassuvium \\
\hline \multirow{3}{*}{2.} & \multirow{3}{*}{ Annonaceae } & Sandat & Cananga adorata \\
\hline & & Blakatak & Polyalthia lateriflora \\
\hline & & Kayu Madas & Polyalthia korinti \\
\hline \multirow{2}{*}{3.} & \multirow{2}{*}{ Apocynaceae } & Pulai/Pule & Alstonia scholaris \\
\hline & & Bukak & Rauwolfia javanica \\
\hline \multirow{2}{*}{4.} & \multirow{2}{*}{ Arecaceae } & Rotan & Calamus axillaris \\
\hline & & Jaka/Aren & Arenga pinnata \\
\hline 5. & Caesalpinioceae & Benul & Parkia speciosa \\
\hline 6. & Clusiaceae & Badung & Garcinia divica \\
\hline 7. & Combretaceae & Kayu Kunyit & Terminalia sumatrana \\
\hline 8. & Cornaceae & Jelit-jelit & Alangium salviifolium \\
\hline 9. & Elaeocarpaceae & Genitri & Elaeocarpus ganitrus \\
\hline 10. & Euphorbiaceae & Buni Hutan & Antidesma bunius \\
\hline \multirow{3}{*}{11.} & \multirow{3}{*}{ Lauraceae } & Bejulitan & Litsea glutinosa \\
\hline & & Кауи Besi & Eusideroxylon zwageri \\
\hline & & Kayu Manis & Cinnamomum burmani \\
\hline 12. & Lecythidaceae & Putat/ Kutat & Planchonia valida \\
\hline 13. & Leeaceae & Gegirang & Leea sp. \\
\hline 14. & Lythraceae & Tangi/Bungur & Lagerstroemia speciosa \\
\hline 15. & Malpighiaceae & Bergiding & Hiptage benghalensis \\
\hline \multirow{8}{*}{16.} & \multirow{8}{*}{ Meliaceae } & Majegau & Dysoxylum densiflorum \\
\hline & & Kayu Adeng & $\begin{array}{l}\text { Dysoxylum } \\
\text { caulostachyum }\end{array}$ \\
\hline & & Kepohpoh & Buchanania arborescens \\
\hline & & Kayu Bawang & Dysoxylum alliaceum \\
\hline & & Kayu Nyoling & Pisnoid umbellata \\
\hline & & Sentul & Sandoricum koetjape \\
\hline & & Mahoni & Swietenia mahagoni \\
\hline & & Langsat Lutung & Aglaia argentea \\
\hline \multirow{7}{*}{17.} & \multirow{7}{*}{ Moraceae } & Beringin Hijau & Ficus benyamina \\
\hline & & Teep/Terep & Artocarpus elastica \\
\hline & & Ae/Ara & Ficus racemosa \\
\hline & & Bunut & Ficus altissima \\
\hline & & Serut/Pungut & Streblus asper \\
\hline & & Каси-Каси & Ficus magnoliaefolia \\
\hline & & Awar-Awar & Ficus septic \\
\hline 18. & Myrisinaceae & Lampeni & Ardisia humilis \\
\hline 19. & Myristicaceae & Kayu Anak & Knema laurina \\
\hline \multirow[t]{2}{*}{20.} & \multirow[t]{2}{*}{ Myrtaceae } & $\begin{array}{l}\text { Kaliampuak/ } \\
\text { Jambu Hutan }\end{array}$ & Eugenia densiflora \\
\hline & & Salam & Syzygium polyanthum \\
\hline 21. & Phyllanthaceae & Gintungan & Bischofia javanica \\
\hline \multirow[t]{2}{*}{22.} & \multirow[t]{2}{*}{ Rubiaceae } & $\begin{array}{l}\text { Kayu Nyan- } \\
\text { Nyan }\end{array}$ & Guettarda speciosa \\
\hline & & Jarum-Jarum & Pavetta subvelutina \\
\hline 23. & Sabiaceae & Kayu Sambuk & Meliosma pinnata \\
\hline 24. & Sapotaceae & Nyantuh & Palaquium javanicum \\
\hline 25. & Sterculiaceae & Bayur & $\begin{array}{l}\text { Pterospermum } \\
\text { javanicum }\end{array}$ \\
\hline 26. & Verbenaceae & Kayu Taluh & Vitex glabrata \\
\hline
\end{tabular}
(1 species), and Leeaceae (1 species). From the floristic list of plants above, then by using literature/document review, interviews, and some relevant information, a rare plant species is obtained as presented in Table III.
TABLE II. LIST OF FLORISTIC SPECIES OF COMMON SPECIES IN ALAS KEDATON TOURISM FOREST TABANAN, BALI, INDONESIA

Source: Wijana in 2018 [46], Wijana and Setiawan in 2017 [47] Notes: *) Local Name Using Balinese 
TABLE III. LIST of RARE Plants SPecies In Alas KedATON TOURISM Forest, TABANAN, BALI, INDONESIA

\begin{tabular}{|c|c|c|c|c|c|}
\hline \multirow{2}{*}{ No. } & \multirow{2}{*}{ Family } & \multicolumn{2}{|l|}{ Name of Plant Species } & \multirow{2}{*}{ Number of Individuals } & \multirow{2}{*}{ Status } \\
\hline & & Local Name*) /Indonesia & Scientific Name & & \\
\hline \multirow{2}{*}{1.} & \multirow{2}{*}{ Anacardiaceae } & Dau & Dracontomelum mangiferum & 8 & $\mathrm{BR}$ \\
\hline & & Mete Mini & Semecarpus cassuvium & 1 & $\mathrm{BR}$ \\
\hline \multirow{3}{*}{2.} & \multirow{3}{*}{ Annonaceae } & Sandat & Cananga adorata & 2 & NR \\
\hline & & Blakatak & Polyalthia lateriflora & 7 & TR \\
\hline & & Kayu Madas & Polyalthia korinti & 17 & MR \\
\hline \multirow{2}{*}{3.} & \multirow{2}{*}{ Apocynaceae } & Pulai/ Pule & Alstonia scholaris & 1 & NR \\
\hline & & Bukak & Rauwolfia javanica & 78 & TR \\
\hline \multirow{2}{*}{4.} & \multirow{2}{*}{ Arecaceae } & Rotan & Calamus axillaris & 6 & $\mathrm{BR}$ \\
\hline & & Jaka/ Aren & Arenga pinnata & 2 & $\mathrm{BR}$ \\
\hline 5. & Caesalpinioidea & Benul & Parkia speciosa & 4 & BR \\
\hline 6. & Clusiaceae & Badung & Garcinia divica & 1 & NR \\
\hline 7. & Combretaceae & Kayи Kunyit & Terminalia sumatrana & 9 & $\mathrm{BR}$ \\
\hline 8. & Elaeocarpaceae & Genitri & Elaeocarpus ganitrus & 1 & $\mathrm{BR}$ \\
\hline 9. & Euphorbiaceae & Buni Hutan & Antidesma bunius & 2 & NR \\
\hline \multirow{3}{*}{10.} & \multirow{3}{*}{ Lauraceae } & Bejulitan & Litsea glutinosa & 26 & BR \\
\hline & & Kayи Besi & Eusideroxylon zwageri & 7 & $\mathrm{BR}$ \\
\hline & & Kayu Manis & Cinnamomum burmani & 57 & TR \\
\hline 11. & Lecythidaceae & Putat/Kutat & Planchonia valida & 12 & BR \\
\hline 12. & Lythraceae & Tangi/Bungur & Lagerstroemia speciosa & 9 & NR \\
\hline 13. & Malpighiales & Bergiding & Hiptage benghalensis & 79 & TR \\
\hline \multirow{8}{*}{14.} & \multirow{8}{*}{ Meliaceae } & Majegau & Dysoxylum densiflorum & 5 & NR \\
\hline & & Kayu Adeng & Dysoxylum caulostachyum & 23 & $\mathrm{BR}$ \\
\hline & & Kepohpoh & Buchanania arborescens & 10 & $\mathrm{BR}$ \\
\hline & & Kayu Bawang & Dysoxylum alliaceum & 60 & TR \\
\hline & & Kayu Nyoling & Pisnoid umbellata & 4 & TR \\
\hline & & Sentul & Sandoricum koetjape & 3 & TR \\
\hline & & Mahoni & Swietenia mahagoni & 63 & MR \\
\hline & & Langsat Lutung & Aglaia argentea & 13 & MR \\
\hline \multirow{6}{*}{15.} & \multirow{6}{*}{ Moraceae } & Beringin Hijau & Ficus benyamina & 1 & NR \\
\hline & & Teep/Terep & Artocarpus elastic & 32 & $\mathrm{BR}$ \\
\hline & & Ae/Ara & Ficus racemosa & 18 & $\mathrm{BR}$ \\
\hline & & Bunut & Ficus altissima & 2 & $\mathrm{BR}$ \\
\hline & & Serut/Pungut & Streblus asper & 2 & TR \\
\hline & & Каси-Каси & Ficus magnoliaefolia & 5 & MR \\
\hline 16. & Myristicaceae & Kayu Anak & Knema laurina & 5 & $\mathrm{BR}$ \\
\hline 17. & Myrtaceae & $\begin{array}{l}\text { Kaliampuak/ } \\
\text { Jambu Hutan }\end{array}$ & Eugenia densiflora & 11 & $\mathrm{TR}$ \\
\hline 18. & Phyllanthaceae & Gintungan & Bischofia javanica & 5 & $\mathrm{BR}$ \\
\hline 19. & Rubiaceae & Kayu Nyan-Nyan & Guettarda speciosa & 4 & $\mathrm{BR}$ \\
\hline 20. & Sabiaceae & Kayu Sambuk & Meliosma pinnata & 3 & $\mathrm{BR}$ \\
\hline 21. & Sapotaceae & Nyantuh & Palaquium javanicum & 34 & $\mathrm{BR}$ \\
\hline 22. & Sterculiaceae & Bayur & Pterospermum javanicum & 11 & NR \\
\hline 23. & Verbenaceae & Kayu Taluh & Vitex glabrata & 1,275 & $\mathrm{TR}$ \\
\hline
\end{tabular}




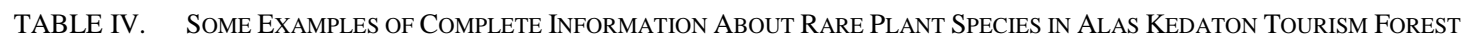

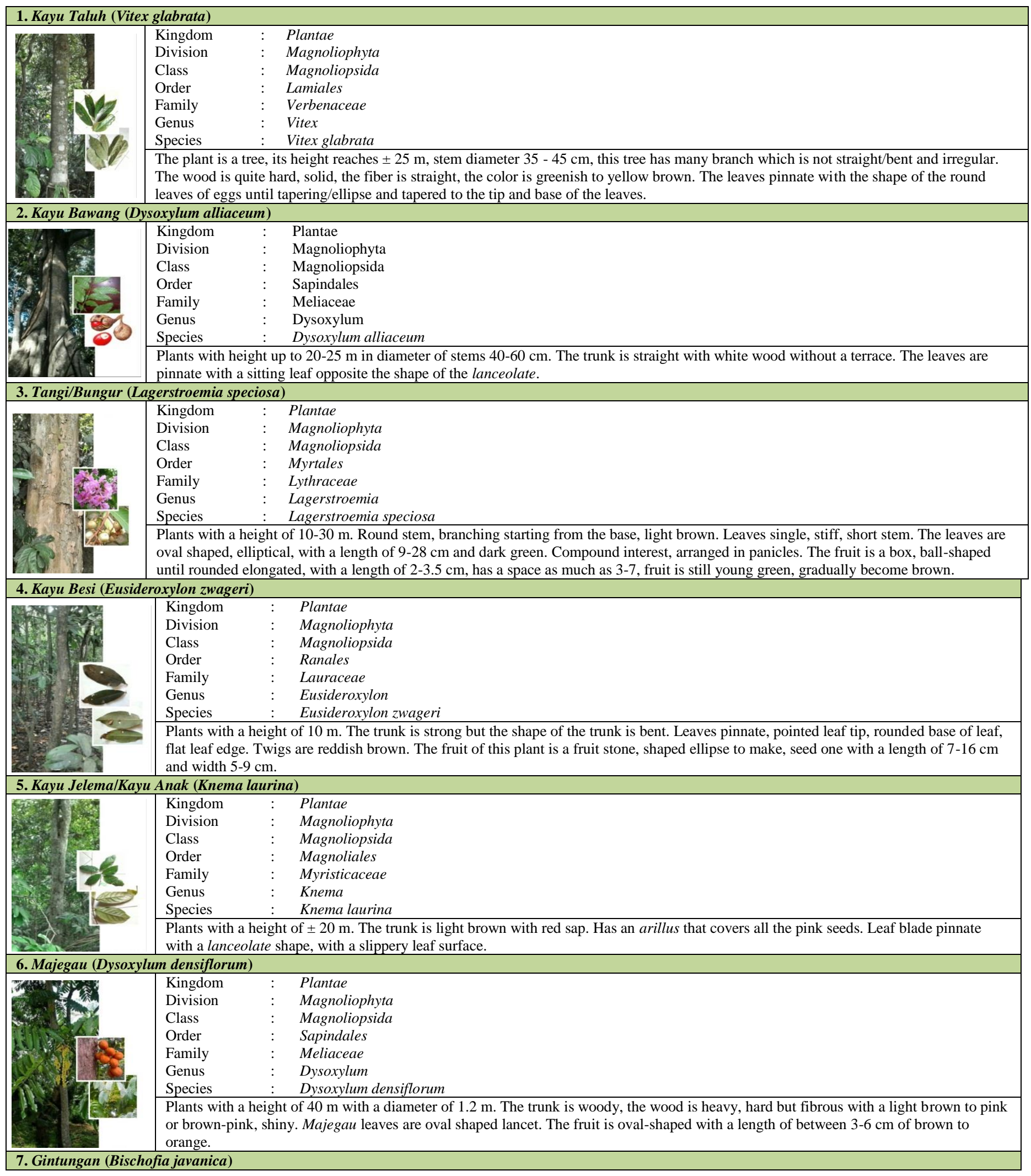




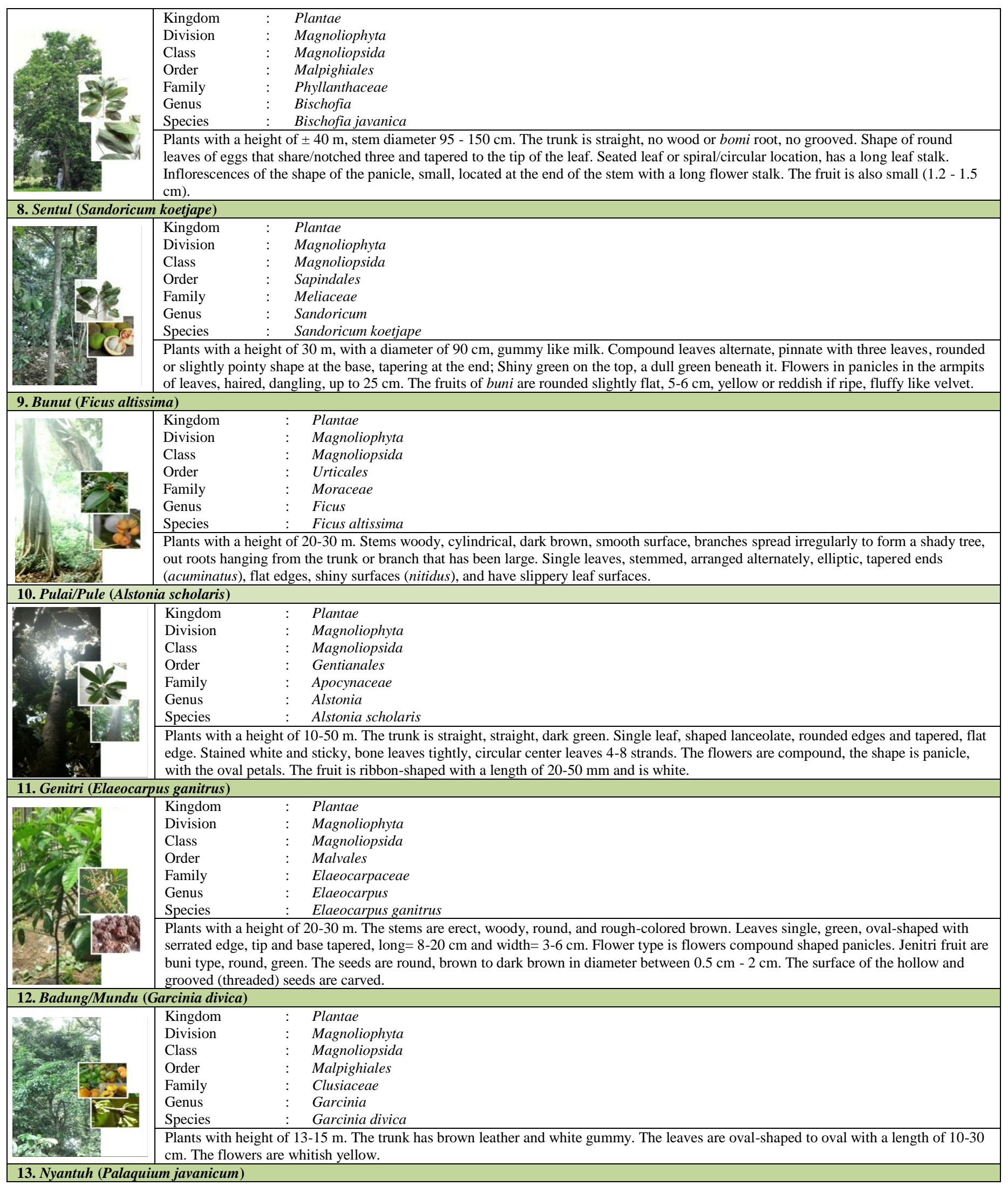




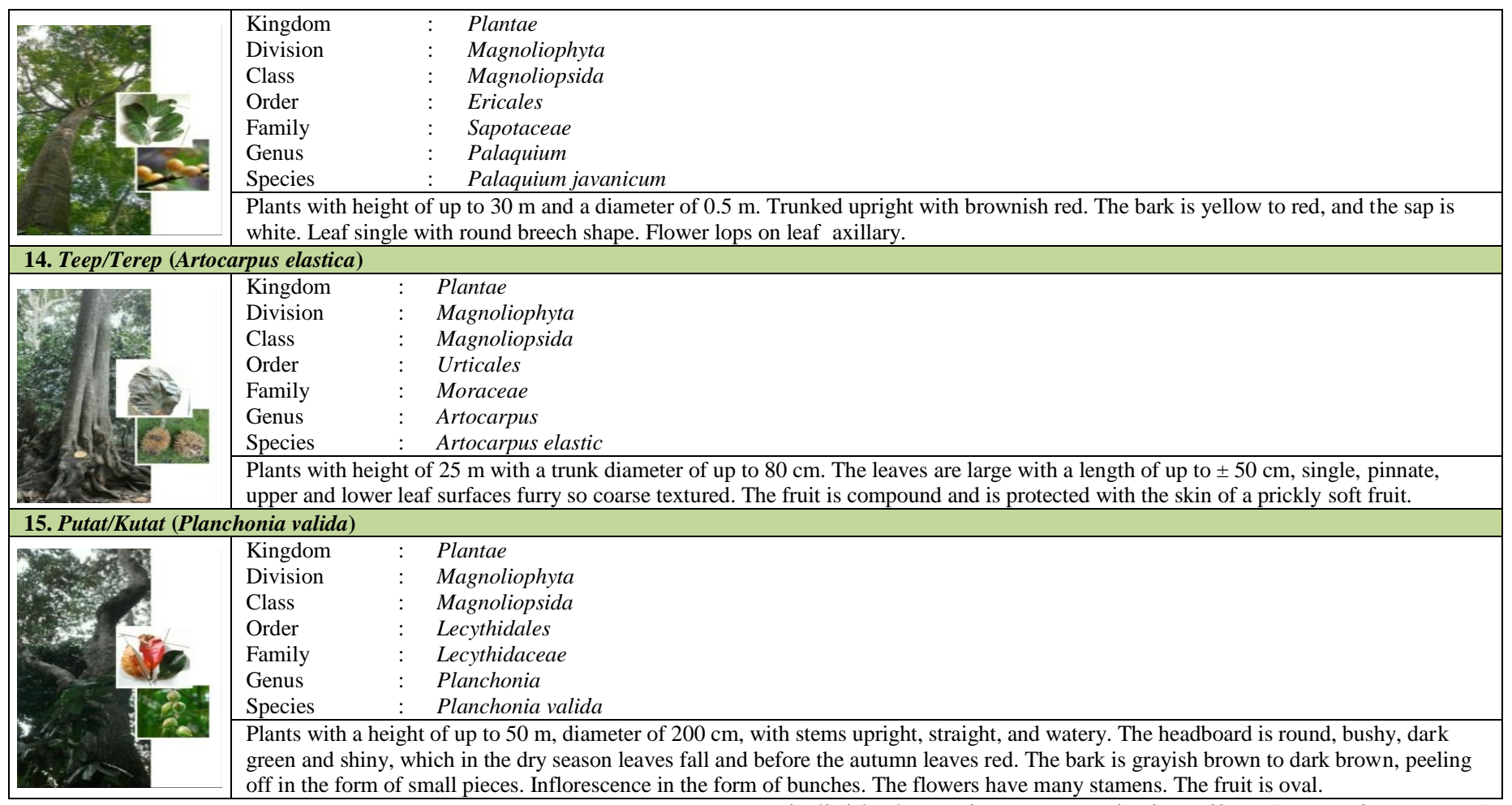

Notes:

NR: National Rare is protected by law [48]

$\mathrm{BR}$ : Rare in Bali is protected by law [48]

TR: Rare in Tabanan regency

MR : Rare in Marga sub-district

*) Local Name Using Balinese Language

From the 48 plant species commonly found in the Alas Kedaton tourism forest, there are as many as $42(87.5 \%)$ plant species belonging to the rare category. This rare plant category is based on document/literature studies with reference to the Forest Service which has established several rare plant species. In addition it is also based on interviews with sources of informants around the Alas Kedaton forest tourism; also, accompanied by interviews to people who generally live outside the Alas Kedaton forest tourism, even to people outside Tabanan regency. From the results of literature studies and interviews with communities and Provincial and District Forestry Offices, rare plant categories such as rare national species, scarce at the level of the Bali province, scarce at level of Tabanan district, and rare at Marga and Kukuh subdistricts. From Table III, it appears that there are $8(19.04 \%)$ plant species belonging to the national rare category, 20 $(47.62 \%)$ of rare plant species at Bali Province level, 10 $(23.81 \%)$ of rare plant species at Tabanan regency level, and 4 $(9.52 \%)$ species belonging to the rare category at Marga subdistrict level, including rare in the Kukuh village level. When viewed from the number of individual species that exist, from the square of $20 \times 20 \mathrm{~m}$ as many as 100 squares obtained species of rare plants with the largest number of individuals is plant species of Kayu Taluh (Vitex glabrata), with an individual number of 1,275 individuals. While the least number of individual species are: Beringin Hijau (Ficus benyamina), Pulai/Pule (Alstonia scholaris), Badung (Garcinia divica), Mete Mini (Semecarpus cassuvium, and Genitri (Elaeocarpus ganitrus), with an each individual number of 1 individual. Thus it can be stated that in the Alas Kedaton forest tourism, as a place of conservation of rare plants, because quite a lot of rare plant species that exist in the forest. It also appears that the number of individuals belonging to the rare plant category is found to be only one individual species in size $20 \times 20 \mathrm{~m} \mathrm{x}$ $100 \mathrm{~m}$ with the interval spacing of $10 \times 20 \mathrm{~m}$; so very apprehensive for plant species with such conditions. This needs special attention for local tourism forest managers. Below are some examples of rare plant species present in Alas Kedaton tourism forest, Tabanan, Bali, Indonesia. Some examples of complete information about rare plant species found in Alas Kedaton tourism forest, Tabanan, Bali, Indonesia can be seen in Table IV.

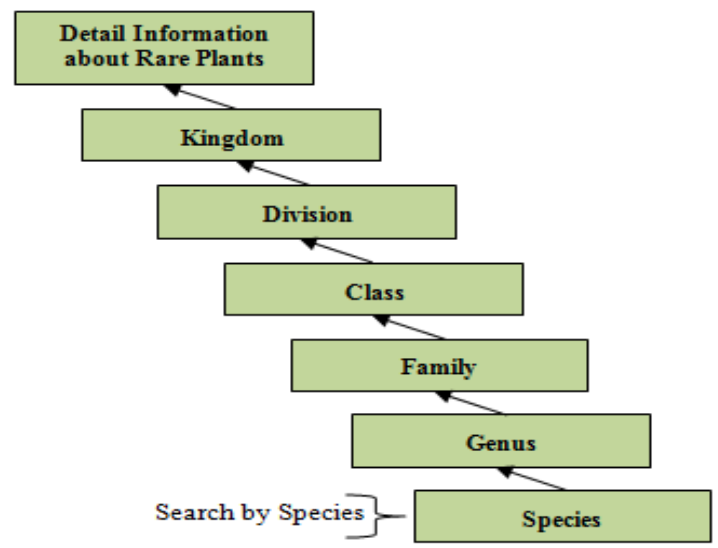

Fig. 1. The Search Process of Detail Information about Rare Plants by Species Name Using Backward Chaining Concept. 


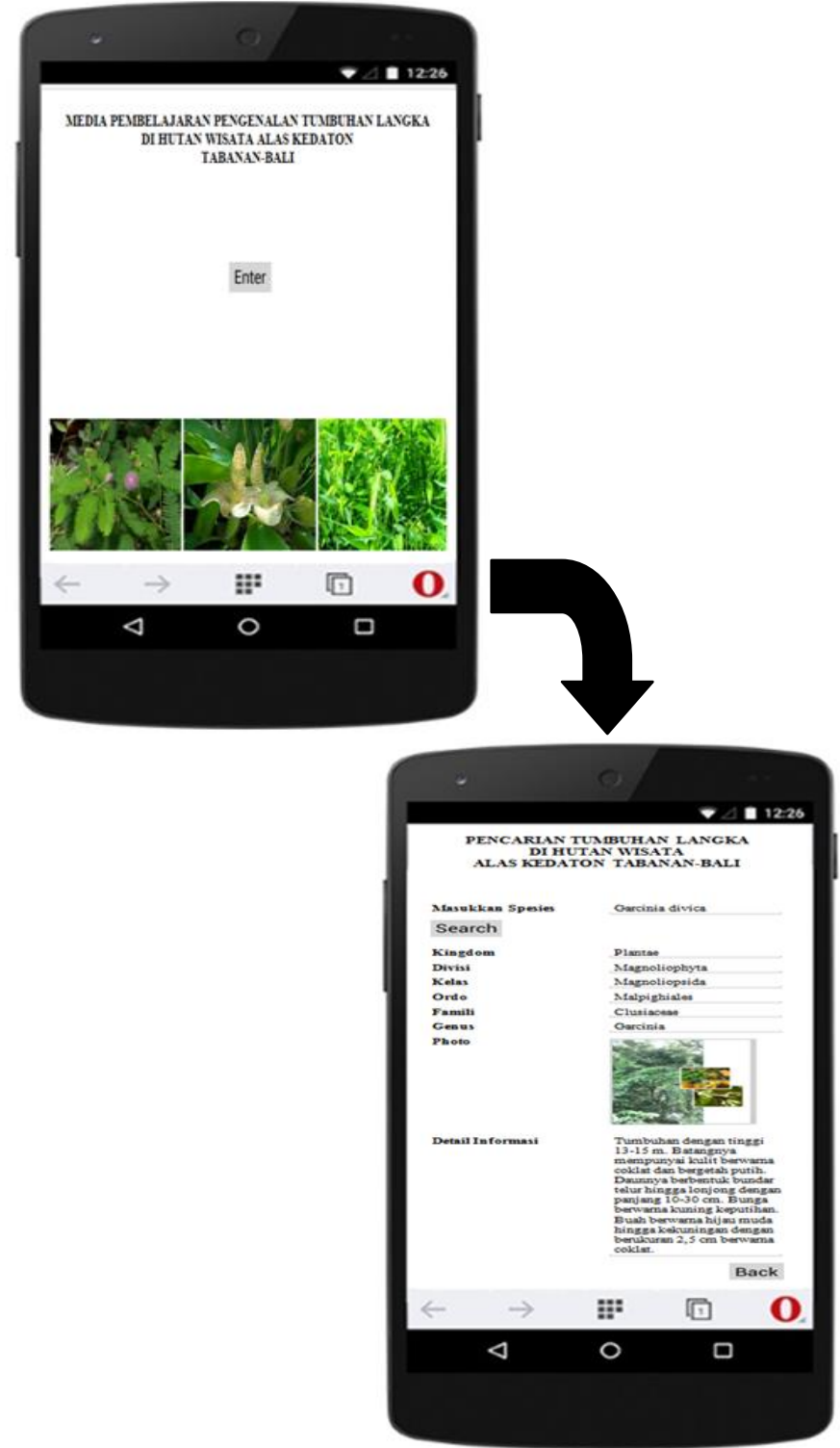

Fig. 2. The Display of Learning Media to Introduce of Rare Plants in Alas Kedaton Tourism Forest, Tabanan, Bali Based on Backward Chaining Concept.

Data from the explorative research results about complete information of rare plant species in Alas Kedaton tourism forest, then used as a knowledge base that is incorporated into the learning media, while the concept of backward chaining is used in searching for complete information about rare plant species. The view of the use of the concept of backward chaining and display of learning media to introduce of rare plants in Alas Kedaton tourism forest, Tabanan, and Bali can be seen in Fig. 1 and 2.

The standard used to measure the effectiveness of use of the media learning to introduce the rare plants in terms of CIPP evaluation model components can be seen in Table V.
TABLE V. MEASUREMENT STANDARD OF EFFECTIVENESS OF USE OF MEDIa LEARNing TO INTRODUCE OF RARE Plants IN TERMS OF CIPP EVALUATION MODEL COMPONENTS

\begin{tabular}{|c|c|c|c|c|}
\hline No & $\begin{array}{l}\text { Evaluation } \\
\text { Components }\end{array}$ & \multicolumn{2}{|c|}{ Evaluation Aspects } & $\begin{array}{l}\text { Measurement } \\
\text { Standard of } \\
\text { Effectiveness (\%) }\end{array}$ \\
\hline \multirow{3}{*}{1.} & \multirow{3}{*}{ Context } & $A_{1}$ & Aim & 88 \\
\hline & & $\mathrm{A}_{2}$ & Legality & 90 \\
\hline & & $\mathrm{A}_{3}$ & Stakeholders Support & 85 \\
\hline \multirow{4}{*}{2.} & \multirow{4}{*}{ Input } & $\mathrm{A}_{4}$ & Facilities and infrastructure & 80 \\
\hline & & $\mathrm{A}_{5}$ & Knowledge Base & 88 \\
\hline & & $\mathrm{A}_{6}$ & Human Resources & 80 \\
\hline & & $\mathrm{A}_{7}$ & Funding & 80 \\
\hline \multirow{4}{*}{3.} & \multirow{4}{*}{ Process } & $A_{8}$ & $\begin{array}{l}\text { The ability of development } \\
\text { team to manage the rule }\end{array}$ & 85 \\
\hline & & $A_{9}$ & $\begin{array}{l}\text { The ability of development } \\
\text { team to manage the } \\
\text { knowledge base }\end{array}$ & 90 \\
\hline & & $A_{10}$ & $\begin{array}{l}\text { The ability of development } \\
\text { team to package/ present the } \\
\text { media to be interactive }\end{array}$ & 85 \\
\hline & & $A_{11}$ & $\begin{array}{l}\text { The ability of users in using } \\
\text { information technology }\end{array}$ & 80 \\
\hline \multirow{4}{*}{4.} & \multirow{4}{*}{ Product } & $A_{12}$ & Interactivity of media & 85 \\
\hline & & $\mathrm{A}_{13}$ & Accuracy of information & 88 \\
\hline & & $\mathrm{A}_{14}$ & Easy access & 85 \\
\hline & & $A_{15}$ & Display of media design & 85 \\
\hline
\end{tabular}

Table V above shows the scores of measurement standard of effectiveness that was used as a basic reference in deciding evaluation. If the measurement results of the learning media to introduce of rare plants in Alas Kedaton tourism forest, Tabanan, Bali shows a less value than the scores of measurement standard of effectiveness, so that the application can be said to be ineffective while if the value is equal or even exceeds of the standard, then the application can be said to be effective. The effectiveness measurement results of the utilization of learning media to introduce of rare plants in Alas Kedaton tourism forest, Tabanan, Bali using CIPP evaluation model can be seen in Table VI.

Table VI above shows the effectiveness measurement results of the use of learning media to introduce of rare plants in Alas Kedaton tourism forest, Tabanan, Bali using CIPP evaluation model, conducted by 25 respondents with giving an assessment of 15 evaluation aspects. Percentage of effectiveness in aspect-1 (aim) was $89.60 \%$, in aspect-2 (legality) was $92.00 \%$, in aspect-3 (stakeholders support) was $85.60 \%$, in aspect-4 (facilities and infrastructure) was $83.20 \%$, in aspect-5 (knowledge base) was $89.60 \%$, in aspect6 (human resources) was $81.60 \%$, in aspect-7 (funding) was $82.40 \%$, in aspect-8 (the ability of development team to manage the rule) sebesar $88.80 \%$, in aspect-9 (the ability of development team to manage the knowledge base) was $92.00 \%$, in aspect-10 (the ability of development team to package/present the media to be interactive) was $89.60 \%$, in aspect-11 (the ability of users in using information technology) was $80.80 \%$, in aspect-12 (interactivity of media) was $88.00 \%$, in aspect-13 (accuracy of information) was $91.20 \%$, in aspect-14 (easy access) was $87.20 \%$, and in aspect-15 (display of media design) was $86.40 \%$. 
TABLE VI. The Measurement Results of EfFectiveness of the Use of Learning Media to Introduce Rare Plants in Alas Kedaton Tourism FOREST, TABANAN, BALI USING CIPP EVALUATION MODEL

\begin{tabular}{|c|c|c|c|c|c|c|c|c|c|c|c|c|c|c|c|c|}
\hline \multirow{4}{*}{ No } & \multirow{4}{*}{ Respondent } & \multicolumn{15}{|c|}{ CIPP Evaluation Component } \\
\hline & & \multicolumn{3}{|c|}{ Context } & \multicolumn{4}{|c|}{ Input } & \multicolumn{4}{|c|}{ Process } & \multicolumn{4}{|c|}{ Product } \\
\hline & & \multicolumn{3}{|c|}{ Context Aspects } & \multicolumn{4}{|c|}{ Input Aspects } & \multicolumn{4}{|c|}{ Process Aspects } & \multicolumn{4}{|c|}{ Product Aspects } \\
\hline & & A1 & A2 & A3 & A4 & A5 & A6 & A7 & A8 & A9 & A10 & A11 & A12 & A13 & A14 & A15 \\
\hline 1 & $\mathrm{R}_{1}$ & 5 & 5 & 4 & 4 & 5 & 4 & 4 & 4 & 5 & 5 & 4 & 4 & 5 & 4 & 4 \\
\hline 2 & $\mathrm{R}_{2}$ & 4 & 5 & 4 & 5 & 4 & 4 & 4 & 5 & 5 & 4 & 4 & 5 & 5 & 4 & 4 \\
\hline 3 & $\mathrm{R}_{3}$ & 4 & 4 & 5 & 4 & 5 & 5 & 4 & 4 & 5 & 5 & 3 & 4 & 5 & 5 & 4 \\
\hline 4 & $\mathrm{R}_{4}$ & 5 & 4 & 4 & 4 & 4 & 4 & 4 & 4 & 4 & 5 & 5 & 5 & 4 & 4 & 5 \\
\hline 5 & $\mathrm{R}_{5}$ & 5 & 5 & 4 & 4 & 4 & 5 & 4 & 4 & 5 & 5 & 5 & 4 & 4 & 4 & 4 \\
\hline 6 & $\mathrm{R}_{6}$ & 4 & 4 & 4 & 4 & 5 & 4 & 5 & 4 & 5 & 5 & 3 & 5 & 5 & 5 & 4 \\
\hline 7 & $\mathrm{R}_{7}$ & 5 & 5 & 4 & 4 & 4 & 4 & 4 & 5 & 4 & 4 & 4 & 4 & 4 & 4 & 4 \\
\hline 8 & $\mathrm{R}_{8}$ & 4 & 4 & 5 & 4 & 5 & 4 & 4 & 5 & 5 & 5 & 4 & 5 & 5 & 5 & 5 \\
\hline 9 & $\mathrm{R}_{9}$ & 4 & 5 & 4 & 5 & 4 & 4 & 4 & 4 & 5 & 4 & 3 & 4 & 4 & 4 & 4 \\
\hline 10 & $\mathrm{R}_{10}$ & 4 & 5 & 4 & 4 & 4 & 5 & 4 & 5 & 4 & 5 & 4 & 4 & 5 & 4 & 4 \\
\hline 11 & $\mathrm{R}_{11}$ & 4 & 5 & 4 & 4 & 4 & 4 & 4 & 4 & 4 & 4 & 4 & 5 & 4 & 5 & 4 \\
\hline 12 & $\mathrm{R}_{12}$ & 4 & 5 & 5 & 4 & 5 & 3 & 4 & 5 & 4 & 5 & 4 & 4 & 4 & 4 & 4 \\
\hline 13 & $\mathrm{R}_{13}$ & 5 & 4 & 4 & 4 & 5 & 4 & 4 & 4 & 5 & 4 & 5 & 5 & 5 & 5 & 5 \\
\hline 14 & $\mathrm{R}_{14}$ & 5 & 5 & 5 & 4 & 5 & 3 & 4 & 4 & 5 & 4 & 4 & 4 & 4 & 4 & 4 \\
\hline 15 & $\mathrm{R}_{15}$ & 5 & 4 & 4 & 4 & 4 & 4 & 4 & 5 & 4 & 4 & 5 & 4 & 5 & 4 & 5 \\
\hline 16 & $\mathrm{R}_{16}$ & 4 & 5 & 5 & 5 & 5 & 3 & 5 & 4 & 5 & 5 & 4 & 5 & 4 & 5 & 5 \\
\hline 17 & $\mathrm{R}_{17}$ & 5 & 4 & 4 & 4 & 4 & 4 & 4 & 5 & 4 & 4 & 3 & 4 & 5 & 4 & 4 \\
\hline 18 & $\mathrm{R}_{18}$ & 4 & 5 & 4 & 4 & 5 & 4 & 4 & 4 & 5 & 4 & 4 & 5 & 4 & 5 & 4 \\
\hline 19 & $\mathrm{R}_{19}$ & 5 & 4 & 4 & 4 & 4 & 4 & 4 & 4 & 4 & 4 & 4 & 4 & 5 & 4 & 5 \\
\hline 20 & $\mathrm{R}_{20}$ & 4 & 5 & 5 & 4 & 5 & 3 & 4 & 5 & 5 & 4 & 5 & 4 & 5 & 5 & 4 \\
\hline 21 & $\mathrm{R}_{21}$ & 4 & 5 & 4 & 5 & 4 & 4 & 4 & 4 & 4 & 5 & 5 & 4 & 4 & 4 & 4 \\
\hline 22 & $\mathrm{R}_{22}$ & 5 & 4 & 4 & 4 & 5 & 5 & 4 & 5 & 5 & 4 & 3 & 5 & 5 & 4 & 5 \\
\hline 23 & $\mathrm{R}_{23}$ & 5 & 5 & 5 & 4 & 4 & 4 & 5 & 5 & 5 & 4 & 4 & 4 & 4 & 5 & 4 \\
\hline 24 & $\mathrm{R}_{24}$ & 4 & 5 & 4 & 4 & 4 & 5 & 4 & 4 & 4 & 5 & 4 & 5 & 5 & 4 & 4 \\
\hline 25 & $\mathrm{R}_{25}$ & 5 & 4 & 4 & 4 & 5 & 5 & 4 & 5 & 5 & 5 & 4 & 4 & 5 & 4 & 5 \\
\hline \multicolumn{2}{|c|}{ Total } & 112 & 115 & 107 & 104 & 112 & 102 & 103 & 111 & 115 & 112 & 101 & 110 & 114 & 109 & 108 \\
\hline \multicolumn{2}{|c|}{$\begin{array}{l}\text { Percentage of Effectiveness } \\
\text { Each Aspect }(\%)\end{array}$} & 89.60 & 92.00 & 85.60 & 83.20 & 89.60 & 81.60 & 82.40 & $\mathbf{8 8 . 8 0}$ & 92.00 & 89.60 & 80.80 & 88.00 & 91.20 & 87.20 & 86.40 \\
\hline \multicolumn{2}{|c|}{\begin{tabular}{|l|} 
Percentage of Effectiveness \\
Each Component $(\%)$
\end{tabular}} & \multicolumn{3}{|c|}{89.07} & \multicolumn{4}{|c|}{84.40} & \multicolumn{4}{|c|}{90.13} & \multicolumn{4}{|c|}{88.80} \\
\hline \multicolumn{2}{|c|}{\begin{tabular}{|l|} 
Average of Overall \\
Components $(\%)$
\end{tabular}} & \multicolumn{15}{|c|}{88.20} \\
\hline
\end{tabular}

Based on the percentage of effectiveness in each aspect, so the percentage of effectiveness on Context components can be determined by the amount of $89.07 \%$ (including the effectiveness level in the good category). The Input Component was $84.40 \%$ (including the effectiveness level in the good category). The Process component was $90.13 \%$ (including the effectiveness level in the good category). The Product component was $88.80 \%$ (including the effectiveness level in the good category). The measurement results of the effectiveness of the use of learning media to introduce of rare plants in Alas Kedaton tourism forest, Tabanan, Bali using CIPP evaluation model based on mobile technology can be seen in Fig. 3.

Based from Table III it is clear that there are as many as 42 $(87.5 \%)$ rare plant species from a total of 48 plant species present in the Alas Kedaton tourism forest. Meanwhile, according to the Provincial Forestry Office of Bali in 1987 from about 200 rare plants in Indonesia which IUCN category
(International Union for Conservation of Nature) in 1987, as many as 32 plants are already known in Bali. The amount of vegetation/flora in the Alas Kedaton tourism forest conducted in 2003 and 2005, the type of plants at this time experiencing a change that increases. In 2003 and 2005, 29 species of rare plants from 43 plant species were identified, while 42 species of rare plants from 46 plant species were identified.

That change is influenced by various factors from the environment and the activity of living things in it. Indriyanto in 2006 [49] explained that community of plants have dynamics or changes, both caused by the activity of nature and humans. Sugita in 2015 [50] explains that changes in the natural environment or the composition of plants in a region can be caused by adaptation to soil environment, topography, geology and climate conditions, through changes in body and function, while the environment also undergoes changes through physical or biogeochemical processes to maintain quality Life support and balance of community systems. 


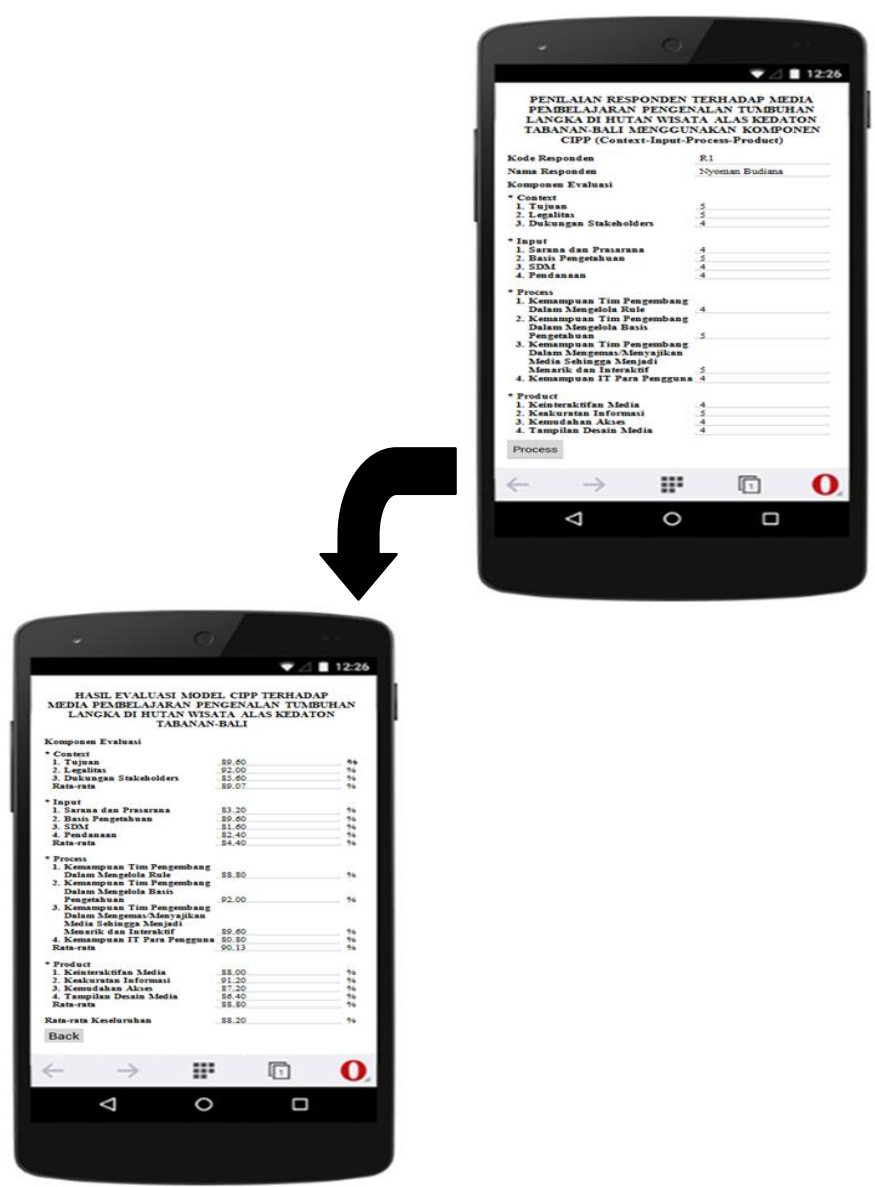

Fig. 3. The Display of Measurement Results of the use of Rare Plants Learning Media using CIPP Evaluation Model Based on Mobile Technology.

\section{B. Discussion}

The statement is in accordance with the results of interviews with the manager of Alas Kedaton tourism forest explained that changes in the composition of plants that have changed the occurrence of the number of rare plants that exist today, due to the efforts of planting plants in forest tours by the spread of new plant seeds. On the other hand, the existence of rare plants in the forest area, is old and dead, and not accompanied by replanting. In addition, according to the forest manager, some plants also died due to the influence of animal disturbance in this forest area, especially animal group "Pteropus vampyrus" which occupy the plant "Pterospermum javanicum" as its habitat, thus disrupting the growth of the tree.

There are several opinions that suggest a plant species may become scarce. The factors that causing plants to become scarce, can be grouped as follows: 1) Rare naturally as a result of a-biotic factors (fire, drought) or biotic (pest or disease). This naturally occurring scarcity process is especially susceptible to endemic plant species that are clustered in certain areas such as the Rafflesia arnoldi plant in West Sumatra or non-endemic plants but relatively small populations and very distant population distribution such as Sawo Kecik (Manilkara kauki) plant in Blambangan Jawa East, West Bali Grand Prapat, and Pedan in Sumbawa. Theoretically, the loss or scarcity of a species will affect the survival of other co-evolutionary species [51]; 2) Rare as a result of human actions directly or indirectly. It can directly be an excessive exploration of a particular plant without adequate rehabilitation efforts e.g. Кауи Eben (Diospyros celebica) in Sulawesi. Indirectly, for example [52], forest destruction due to air pollution or acid rain in industrialized countries such as the Picea abiex plant in West Germany with damage of about $9 \%$ in 1982 accelerated to $51 \%$ in 1984 .

From the results of in-depth interviews in the field, the factor of the occurrence of scarcity of rare plant species in the Alas Kedaton forest tourism are: 1) Environmental degradation factors. In this context it means that the present forests, inherited by the younger generation of the village today, are the remnants of the ancient forest, which now extend to 27 hectares. While the former, the extent of more than today. The age of their parents in the past, many converted the forest into agricultural areas. The current forest area, left to not be felled because in it there Pura as a holy place for Hindus to pray. So that the remaining forests are now believed to be a sacred place for Hindus in Bali; 2) Plants belonging to the rare category, seen from the way of reproduction, take place very slowly, so that the parents are very uninteresting to breed it; Thus its proliferation only takes place naturally, and its survival also takes place naturally; 3) Plants that are included in rare plants, have a high enough quality of wood, so many plants that live outside the forest of this tour, felled and used for building materials; 4) Rare plants considered as "sacred wood" by the people, often used for holy shrines (Hindu temples in Bali) or for religious ceremonies (Hindu), are not accompanied by breeding or breeding as materials Replacement of harvested plants; 5) The absence of an attempt to breed rare plants by forest managers and by surrounding communities. This effort is not done related to the increasingly difficult to find rare plants around their environment. Although the economic value is quite high, but because it is very rarely found in nature, the community turns to other timber, which is more practical, interesting and qualified to be used as a building material or as a reforestation material; 6) In the Alas Kedaton tourism forest, many rare plants are also dead, due to the disturbance of animals, especially long-tailed monkeys (Macaca fascicularis) and bats (Pteropus vampyrus), which are increasingly population. Herbs are often used as a place to play and many plants are "disturbed". Ecologically edible fruits are used as feed by some of the monkey populations and bats in the forest. Seeds that grow are often eaten or disturbed or broken so that the seeds of these plants to death.

Based on the average of effectiveness percentage of use of learning media to introduce of rare plants in Alas Kedaton tourism forest, Tabanan, Bali in terms of the overall component of CIPP evaluation model, it can be explained that in general the learning media can already function and good categorized because overall the average percentage of effectiveness level if viewed from all components obtained percentage of $88.20 \%$. The results are reinforced with and proven from the average percentage of effectiveness level on the context component of $89.07 \%$ so that included in good category, the input component of $84.40 \%$ so that included in good category, on the process component of $90.13 \%$ so that 
included in the category very good, And on product component equal to $88.80 \%$ so that included in good category.

Based on the comparison between the measurement results of effectiveness (shown in Table VI) with measurement standard of effectiveness (shown in Table V), so the learning media can be said to be effective on aspect-1, because the score of measurement results on aspect- 1 was $89.60 \%$ having a higher score than the score of measurement standard amount of $88.00 \%$. The learning media can be said to be effective on aspect-2, because the score of measurement results on aspect- 2 was $92.00 \%$ having a higher score than the score of measurement standard amount of $90.00 \%$. The learning media can be said to be effective on aspect-3, because the score of measurement results on aspect- 2 was $85.60 \%$ having a higher score than the score of measurement standard amount of $85.00 \%$. The learning media can be said to be effective on aspect-4, because the score of measurement results on aspect2 was $83.20 \%$ having a higher score than the score of measurement standard amount of $80.00 \%$. The learning media can be said to be effective on aspect-5, because the score of measurement results on aspect- 5 was $89.60 \%$ having a higher score than the score of measurement standard amount of $88.00 \%$. The learning media can be said to be effective on aspect-6, because the score of measurement results on aspect- 6 was $81.60 \%$ having a higher score than the score of measurement standard amount of $80.00 \%$. The learning media can be said to be effective on aspect-7, because the score of measurement results on aspect- 7 was $82.40 \%$ having a higher score than the score of measurement standard amount of $80.00 \%$. The learning media can be said to be effective on aspect- 8 , because the score of measurement results on aspect- 8 was $88.80 \%$ having a higher score than the score of measurement standard amount of $85.00 \%$. The learning media can be said to be effective on aspect-9, because the score of measurement results on aspect-9 was $92.00 \%$ having a higher score than the score of measurement standard amount of $90.00 \%$. The learning media can be said to be effective on aspect-10, because the score of measurement results on aspect-10 was $89.60 \%$ having a higher score than the score of measurement standard amount of $85.00 \%$. The learning media can be said to be effective on aspect-11, because the score of measurement results on aspect-11 was $80.80 \%$ having a higher score than the score of measurement standard amount of $80.00 \%$. The learning media can be said to be effective on aspect-12, because the score of measurement results on aspect-12 was $88.00 \%$ having a higher score than the score of measurement standard amount of $85.00 \%$. The learning media can be said to be effective on aspect-13, because the score of measurement results on aspect-13 was $91.20 \%$ having a higher score than the score of measurement standard amount of $88.00 \%$. The learning media can be said to be effective on aspect-14, because the score of measurement results on aspect-14 was $87.20 \%$ having a higher score than the score of measurement standard amount of $85.00 \%$. The learning media can be said to be effective on aspect-15, because the score of measurement results on aspect- 15 was $86.40 \%$ having a higher score than the score of measurement standard amount of $85.00 \%$. Obstacles found in this research is that the knowledge base is still limited from the results of explorative research on rare plants in the Alas Kedaton forest tourism only, whereas in other forests there are actually other species that may have the same characteristics or even provide more complete information than obtained in the Alas Kedaton tourist forest.

\section{CONCLUSIONS}

There are 48 species of plants that generally exist in the Alas Kedaton forest tourism. Of these, there are $42(87.5 \%)$ plant species belonging to the rare category. Of the 42 species of rare plants present in the Alas Kedaton forest, there are 8 $(19.04 \%)$ plant species belonging to the national rare category, $20(47.62 \%)$ of rare plant species in Bali, $10(23.81 \%)$ rare plant species in Tabanan District, and 4 (9.52\%) species falling into the rare category at the Sub District level (especially Marga Sub-district).

The factors causing the scarcity of plant species present in the Alas Kedaton tourism forest are: 1) the degradation of the ancient environment, 2) the problem of reproduction of rare plants, 3) Human Intervention, 4) Disorders by animals, especially long-tailed monkeys (Macaca fascicularis) and bats (Pteropus vampyrus). Level of effectiveness of utilization of learning media to introduce of rare plants in Alas Kedaton tourism forest for students and general public is categorized in good category because in whole if evaluated from all component of evaluation CIPP model obtained the average effectiveness percentage of $88.20 \%$.

Future works that can be done to overcome the constraints related to the knowledge base is finding out a source of knowledge based on explorative research in other locations and find sources in books or other related literature either from libraries or through the internet and also can develop applications with the use of data mining concept.

\section{ACKNOWLEDGMENTS}

The authors would like to extend their gratitude to all faculty members of Universitas Pendidikan Ganesha and IKIP PGRI Bali, who assisted in the completion of this research.

\section{REFERENCES}

[1] Direktorat Jendral Planologi Kehutanan. (2010). Data dan Kesatuan Pengelolaan Hutan 2010. Jakarta: Kementerian Kehutanan Republik Indonesia.

[2] Departemen Kehutanan. (2010). Risalah Hutan Lindung di Wilayah KPH Bali Tengah dan Bali Timur Dinas Kehutanan Provinsi Dati 1 Bali. Singaraja: Balai Inventarisasi dan Perpetaan Hutan.

[3] Wijana, N., and Sumardika. I.N. (2004). Penentuan Kualitas Air Danau Batur (Kajian dari Sisi ABC Envirotment. Singaraja: Universitas Pendidikan Ganesha.

[4] Wijana, N., and Sumardika. I.N. (2005). Analisis Vegetasi Hutan Bukit Kangin Desa Adat Tenganan Pengringsingan, Kabupaten Karangasem. Singaraja: Universitas Pendidikan Ganesha.

[5] Wijana, N., Sutajaya, M. and Kariasa. N. (2006). Analisis Kualitas Air, Aspek Kesehatan Masyarakat, Vegetasi Penyangga dan Upaya Pengelolaan oleh Masyarakat Seputar Danau Batur Kecamatan Kintamani Kabupaten Bangli. Singaraja: Universitas Pendidikan Ganesha.

[6] Wijana, N. (2008). "Keanekaragaman Spesies Tumbuhan, Manfaat dan Upaya Pelestariannya," Jurnal Matematika dan Sains, Vol. 5, No. 10, pp.17-34

[7] Wijana, N., and I.N. Sumardika, I.N. (2009). "Pelestarian Jenis-Jenis Tumbuhan Berguna Melalui Kearifan Lokal di Desa Adat Tenganan Pegringsingan, Kabupaten Karangasem, Bali," Proceeding Konservasi Flora Indonesia Dalam Mengatasi Dampak Pemanasan Global, pp. 724- 731 . 
[8] Wijana, N., Swasta, I.B.J., and Sumardika, I.N. (2010). Analisis ABC Environment Pada Ekosistem Tumpang Tindih (Overlap Ecosystem) dalam Kaitannya dengan Penurunan Kualitas Air, Eutrofikasi, dan Rencana Pemantauan Lingkungan (RPL) Danau Buyan Kecamatan Sukasada Kabupaten Buleleng. Singaraja: Universitas Pendidikan Ganesha, 2010.

[9] Wijana, N. (2012). Analisis Dampak Lingkungan dan Upaya Pengelolaan Berbasis Ergologi Kawasan Wisata Lovina, Buleleng Bali. Singaraja: Universitas Pendidikan Ganesha.

[10] Wijana, N. (2013). Analisis Vegetasi Hutan Adat, Upaya Pengelolaan Berbasis Kearifan Lokal dan Pemberdayaan Masyarakat Melalui Pendekatan Ergologi di Desa Bali Aga Buleleng-Bali. Singaraja: Universitas Pendidikan Ganesha.

[11] Wijana, N. (2014). "Analisis Komposisi dan Keanekaragaman Spesies Tumbuhan di Hutan Desa Bali Aga Tigawasa, Buleleng-Bali," Jurnal Sains dan Humaniora Lemlit Undiksha, Vol. 1, No. 1, pp. 55-65.

[12] Wijana, N. (2015). Analisis Dampak Lingkungan Terhadap Aktivitas Pembudidayaan Udang dengan Sistem Kurungan di Laut Lepas Desa Sangsit Kecamatan Sawan, Kabupaten Buleleng, Bali. Singaraja: Universitas Pendidikan Ganesha.

[13] Wijana, N. (2016). Pengelolaan Lingkungan Hidup (Aspek Kearifan Lokal, Ergonomi, Ergologi, dan Regulasi). Singaraja: Undiksha Press.

[14] Wijana, N. (2016). Analisis Kualitas Lingkungan ditinjau dari aspek ABC Enviruntment di Kawasan Wisata Toya Bungkah, Bangli. Singaraja: Universitas Pendidikan Ganesha.

[15] Wijana, N. (2016). Penentuan Titik-titik Rawan Erosi Sepanjang Jalur Wisata Bedugul-Singaraja. Singaraja: Universitas Pendidikan Ganesha.

[16] Arrijani, Setiadi, D., Guhardja, E., and Qayim, I. (2006). "Analisis Vegetasi Hulu DAS Cianjur Taman Nasional Gunung Gede-Pangrango," Jurnal Biodiversitas, Vol.7, No. 2, pp. 147-153.

[17] Hartini, S. (2007). "Keragaman Flora dari Monumen Alam Kersik Luway Kalimantan Timur," Jurnal Biodiversitas, Vol. 8, No. 1, pp. 6772.

[18] Purwaningsih. (2006). "Analisis Vegetasi Hutan pada Beberapa Ketinggian Tempat di Bukit Wawouwai, Pulau Wawonii Sulawesi Tenggara," Jurnal Biodiversitas, Vol. 7, No. 1, pp. 49-53.

[19] Purwaningsih, and Yusuf, R. (2008). "Analisis Vegetasi Hutan Pegunungan di Taman Nasional Gunung Ciremai, Majalengka, Jawa Barat," Jurnal Biologi Indonesia, Vol. 4, No. 5, pp.385-399.

[20] Junaedi, Indrawan, D., and Mutaqien, Z. (2010). "Diversity of Tree Communities in Mount Patuha Region, West Java", Biodiversitas, Vol. 11, No. 2, pp. 75-81.

[21] Onrizal, Kusmono, C., Saharjo, B. H., Handayani, I.P., and Koto, T. (2006). "Analisis Vegetasi Hutan Hujan Tropika Dataran Rendah Sekunder di Taman Nasional Danau Sentarum, Kalimantan Barat," Jurnal Biologi, Vol. 4, No. 6, pp. 359-371.

[22] Sujaya, I.M. (2007). Warga Kukuh Pantang Tebang Pohon di Alas Kedaton (access from_http://www.balisaja.com/2007/12/warga-kukuhpantang-tebang-pohon-di.html)

[23] Divayana, D.G.H., and Sanjaya, D.B. (2017). "Mobile Phone-Based CIPP Evaluation Model in Evaluating the Use of Blended Learning at School in Bali," International Journal of Interactive Mobile Technologies, Vol. 11, No. 4, pp.149-159.

[24] Jampel, I.N., Lasmawan, I.W., Ardana, I.M., Ariawan, I.P.W., Sugiarta, I.M., \& Divayana, D.G.H. (2017). "Evaluation of Learning Programs and Computer Certification at Course Institute in Bali Using CSEUCLA Based on SAW Simulation Model," Journal of Theoretical and Applied Information Technology, Vol. 95, No. 24, pp. 6934-6949.

[25] Arnyana, I.B.P., Sadia, I.W., Suma, I.K., and Divayana, D.G.H. (2017). "Determination of Effectiveness of Evaluation Results on School Culture and Character of Junior High School Students Using Character Assessment Instruments With The Local Wisdom of Bali Based on Mobile Phone," Journal of Theoretical and Applied Information Technology, Vol. 95, No. 20, pp. 5348-5359.

[26] Divayana, D.G.H., Sanjaya, D.B., Marhaeni, A.A.I.N., and Sudirtha, I.G. (2017). "CIPP Evaluation Model Based on Mobile Phone in Evaluating The Use of Blended Learning Platforms at Vocational Schools in Bali," Journal of Theoretical and Applied Information Technology, Vol. 95. No 9, pp. 1983-1995.
[27] Divayana, D.G.H., Agung, A.A.G., Sappaile, B.I., Simatupang, W., Sastrawijaya, Y., Sundayana, I.M., and Sugiharni, G.A.D. (2017). "Utilization of Open Source Technology in Determining of Validity and Reliability of Evaluation Model Instruments Based on ANEKA Values in Order to Evaluate The Quality of Computer Learning," Journal of Theoretical and Applied Information Technology, Vol. 95, No. 20, pp. 5517- 5534.

[28] Divayana, D.G.H., Sappaile, B.I., Pujawan, I.G.N., Dibia, I.K., Artaningsih, L., Sundayana, I.M., \& Sugiharni, G.A.D. (2017). "An Evaluation of Instructional Process of Expert System Course Program by Using Mobile Technology-Based CSE-UCLA Model," International Journal of Interactive Mobile Technologies, Vol. 11, No. 6, pp. 18- 31.

[29] Divayana, D.G.H., Marhaeni, A.A.I.N., Dantes, N., Arnyana, I.B.P., and W. Rahayu, (2017). "Evaluation of Blended Learning Process of Expert System Course Program by Using CSE-UCLA Model Based on Mobile Technology", Journal of Theoretical and Applied Information Technology, Vol. 95, No. 13, 2017, pp. 3075-3086.

[30] Ariawan, I.P.W, Sanjaya, D.B., and Divayana, D.G.H. (2016). “An Evaluation of the Implementation of Practice Teaching Program for Prospective Teachers at Ganesha University of Education Based on CIPP-Forward Chaining," International Journal of Advanced Research in Artificial Intelligence, Vol. 5, No. 2, pp. 1-5.

[31] Divayana, D.G.H., Ardana, I.M., and Ariawan, I.P.W. (2017). "Measurement of Effectiveness of a Lecturer in Transferring Algebra Knowledge Through of Multimedia Facilities by Using Certainty FactorFormative-Summative Model," Journal of Theoretical and Applied Information Technology, Vol. 95. No 9, pp. 1963-1973.

[32] Divayana, D.G.H. (2015). "Evaluasi Program Penanggulangan HIV/AIDS Dengan Model CIPP Berbantuan Komputer," Konferensi Nasional Sistem \& Informatika, pp.442-446.

[33] Divayana. D.G.H. (2016). Evaluasi Program Perpustakaan Digital Berbasis Sistem Pakar pada Universitas Teknologi Indonesia. Jakarta: Universitas Negeri Jakarta.

[34] Divayana, D.G.H. (2015). "Penggunaan Model CSE-UCLA Dalam Mengevaluasi Kualitas Program Aplikasi Sistem Pakar," SNATIA, pp.165-168.

[35] Divayana, D.G.H. (2017). "Evaluasi Pemanfaatan E-Learning Menggunakan Model CSE-UCLA," Jurnal Cakrawala Pendidikan, Vol. 36, No. 2, pp. 280-289.

[36] Divayana, D.G.H. (2017). "Utilization of CSE-UCLA Model in Evaluating of Digital Library Program Based on Expert System at Universitas Teknologi Indonesia: A Model for Evaluating of Information Technology-Based Education Services," Journal of Theoretical and Applied Information Technology, Vol. 95, No. 15, pp. 3585-3596.

[37] Sanjaya, D.B., and Divayana, D.G.H. (2015). "An Expert System-Based Evaluation of Civics Education as a Means of Character Education Based on Local Culture in the Universities in Buleleng," International Journal of Advanced Research in Artificial Intelligence, Vol. 4, No. 12, pp. 17-21.

[38] Divayana, D.G.H., and Sugiharni, G.A.D. (2016). "Evaluasi Program Sertifikasi Komputer Pada Universitas Teknologi Indonesia Menggunakan Model CSE-UCLA," Jurnal Pendidikan Indonesia, Vol. 5, No. 2, pp. 865-872.

[39] Divayana, D.G.H., Adiarta, A., and Abadi, I.B.G.S. (2017). "Conceptual and Physical Design of Evaluation Program for Optimizing Digital Library Services at Computer College in Bali Based on CSE-UCLA Model Modification with Weighted Product," Journal of Theoretical and Applied Information Technology, Vol. 95, No. 16, pp. 3767-3782.

[40] Suandi, I.N., Putrayasa, I.B., and Divayana, D.G.H. (2017). "Compiling a Dictionary of Loan Words in Balinese: The Evaluation Result of Effectiveness Testing in The Field Aided by Mobile Technology," Journal of Theoretical and Applied Information Technology, Vol. 95, No. 14, pp. 3186-3195.

[41] Divayana, D.G.H., Adiarta, A., and Abadi, I.B.G.S. (2018). "Initial Draft of CSE-UCLA Evaluation Model Based on Weighted Product in Order to Optimize Digital Library Services in Computer College in Bali," IOP Conference Series: Materials Science and Engineering, Vol. 296, 2018, pp. 12-17. 
[42] Sudiana, I.K., Rahayu, W., Santiyadnya, N., Parmithi, N.N, Mahendra, I.W.E., and Divayana, D.G.H. (2018). "Mapping Sports Tourism in Buleleng-Bali Using Goal-oriented Evaluation Model Based on SAW," Journal of Theoretical and Applied Information Technology, Vol. 96, No. 13, 2018, pp. 4157-4169.

[43] Mahayukti, G.A., Dantes, N., Candiasa, I.M., Marhaeni, A.A.I.N., Gita, I.N., and Divayana, D.G.H. (2018). "Computer-based Portfolio Assessment to Enhance Students' Self-Regulated Learning", Journal of Theoretical and Applied Information Technology, Vol. 96, No. 8, 2018, pp. 2351- 2360.

[44] Barbour, M.G., Burk, J.H., and Pitts, W.D. (1987). Terrestrial Plant Ecology. California: The Benjamin/Cummings Publishing Company Inc.

[45] Subana, M., and Sudrajat. (2001). Dasar-Dasar Penelitian Ilmiah. Bandung: CV. Pustaka Pelajar.

[46] Wijana, N. (2018). Ensiklopedia Floristik Tumbuhan Langka. Yogyakarta: Plantaxia.
[47] Wijana, N., and Setiawan, I.G.A.N. (2017). Pemetaan Pencaran dan Pola Sebaran Spesies Tumbuhan Langka Serta Upaya Pengelolaan Berbasis Kearifan Lokal Pada Hutan Wisata di Propinsi Bali (Laporan Hasil Penelitian). Singaraja: LPPM Universitas Pendidikan Ganesha.

[48] Peraturan Pemerintah Republik Indonesia No. 7 Tahun 1999.

[49] Indriyanto. (2008). Ekologi Hutan Cetakan ke-2. Jakarta: Bumi Aksara.

[50] Sugita, W. (2015). Dampak Perkembangan Pariwisata Terhadap Keberlanjutan Usahatani Rumput Laut di Desa Kutuh, Kuta Selatan Kabupaten Badung. Denpasar: Universitas Udayana.

[51] Sarna, K. (1993). Inventarisasi dan Pelestarian Tanaman Langka di Bali dalam Usaha Menunjang Obyek Wisata dan Studi. Singaraja: FKIP Unud.

[52] Soemarwoto, O. (1991). Indonesia Dalam Kancah Isu Lingkungan Global. Jakarta: PT. Gramedia Pustaka Utama. 